\title{
NEW DATA ON THE DISTRIBUTION OF BRYUM MINII (BRYACEAE, BRYOPHYTA) IN PORTUGAL WITH ECOLOGICAL AND CHOROLOGICAL CONSIDERATIONS
}

\author{
Cecília SÉrgio ${ }^{1}$, César Augusto Garcia \& SARAH Stow
}

\begin{abstract}
Bryum minii Podp. ex Machado-Guim. was first described from Portugal in the nineteenth century and only recorded in Spain in 2010. It is found on acidic rocks, such as granite, near watercourses and its glossy appearance makes it relatively easy to identify in the field although it grows in small patches. New chorological data are provided for Portugal, as well as species photographs and an updated distribution map which show that it is no longer a rare species in Portugal and can therefore not be considered threatened. It is likely that more records of this moss will be found with new fieldwork in riparian communities.
\end{abstract}

Key words. Bryum minii, European endemic, Portugal, distribution map, ecology

Cecília Sérgio \& César Augusto Garcia, Museu Nacional de História Natural e da Ciência/Centro de Biologia Ambiental, Universidade de Lisboa, Rua da Escola Politécnica, 58, 1250-102 Lisboa, Portugal; e-mail: csergio@fc.ul.pt

Sarah Stow, Department of Life Sciences, The Natural History Museum, London, SW7 5BD, UK \& Durrell Institute of Conservation \& Ecology, School of Anthropology \& Conservation, University of Kent, Canterbury, CT2 7NR, UK; e-mail: s.stow@nhm.ac.uk

Bryum minii Podp. ex Machado-Guim. is an interesting moss in Portugal (Sérgio et al. 1999), found in areas with other bryophyte taxa of high phytogeographic importance or endemic to the Iberian Peninsula, such as Anomobryum lusitanicum Thériot, Claopodium whippleanum (Sull.) Ren. \& Card., Dicranum crassifolium Sérgio, Ochyra \& Séneca, Racomitrium hespericum Sérgio, Ochyra \& Muñoz and Schizymenium pontevedrense (Luis.) Casas, Sérgio, Cros \& Brugués (Sérgio \& Draper 2001).

This Bryum species is relatively easy to recognize in the field by its glossy appearance with a slight metallic sheen and rosulate leaves, which are spirally twisted when dry, but completely distinct from $B$. capillare Hedw. The plants are relatively small ( $c a 10-12 \mathrm{~mm}$ ), forming dense tufts, yellowish green to red-brown below, with dense reddish brown rhizoids and with leaves that are ovate to oblong, concave, slightly acute with a shortly pointed apex (Fig. 1).

Bryum minii was collected for the first time by Machado in Portugal in the beginning of the nineteenth century (Machado 1916), as Bryum mar-

\footnotetext{
1 Corresponding author
}

ginatum Bruch \& Schimp., and later some more new Portuguese localities were given in his flora (Machado 1930), again under the same name. The first reference of this species in Spain was only very recently given by Cezón et al. (2010) who present new taxonomic information and describe a new Spanish record. This species' presence has been confirmed in Sardinia in the recent list of Mediterranean bryophytes from a single location (Ros et al. 2013), and recently reported in France (Skrzypczak 1998), therefore making this species an endemic European taxon (Sérgio et al. 1999).

The general distribution indicates that this plant presents oceanic and Mediterranean affinities, found in areas with warm temperate climates. In Portugal B. minii grows in granite regions, in rock crevices and on banks near small streams, at altitudes from $50 \mathrm{~m}$ to $1450 \mathrm{~m}$ a.s.1.

The number of $10 \mathrm{~km}$ UTM squares in 1950 was only 4, but subsequently Sérgio and Draper (2002) produced a new cartographic distribution with $\mathrm{ca} 15$ and it is now reported from a large number of UTM squares and localities, ca 40 (Fig. 2). In the recent Iberian Flora it is considered to be present in Alto Alentejo, Beira Alta, Beira 

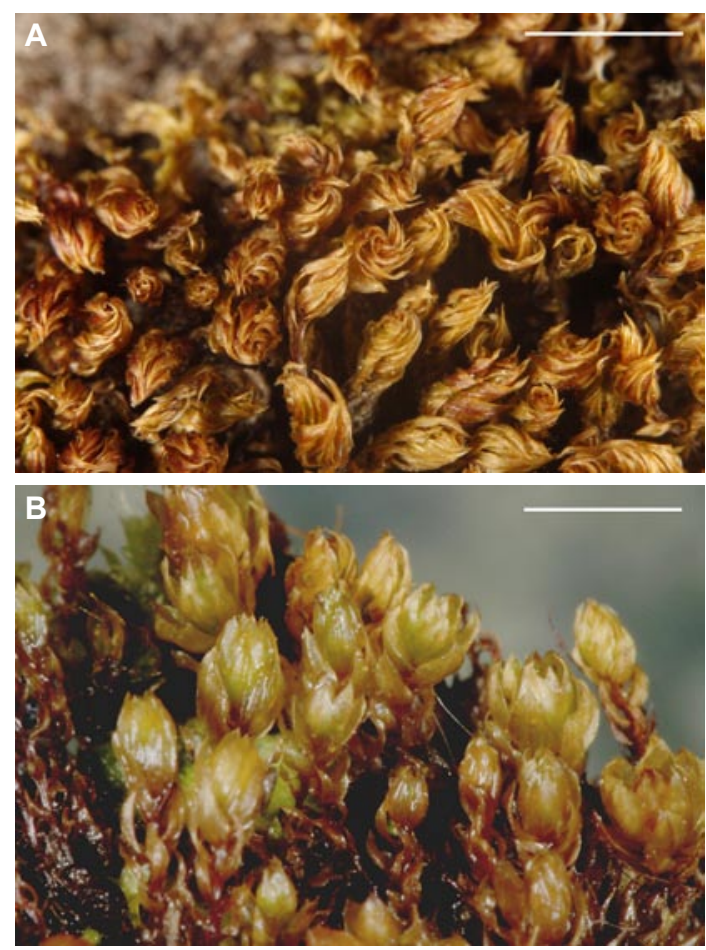

Fig. 1. Habit of Bryum minii Podp. ex Machado-Guim. growing in a typical mat, showing dry plants with spirally twisted leaves (A) and hydrated plants (B). Scale bars: A \& B $=4 \mathrm{~mm}$.

Baixa, Douro Litoral, Minho and Trás-os-Montes e Alto Douro (Guerra et al. 2010), although in this last province no specific locality is given.

In recent years we have found various new areas (Fig. 2), not only in Trás-os-Montes e Alto Douro but also in Beira Alta and in Beira Baixa (Sérgio et al. 2011), where the species can be frequent. In the majority of the known localities the moss grows in small populations covering between $25 \mathrm{~cm}^{2}$ and $100 \mathrm{~cm}^{2}$. To this present moment this moss has apparently always been rare and found in small quantities.

In Spain it is so far reported from a few localities in only four different provinces: Álava, Cáceres, Ciudad Real and Toledo (Guerra et al. 2010).

Based on these new recent collections we now consider that B. minii is not a rare species in Portugal, as already pointed out in Sérgio et al. (1999), and cannot be considered a threatened species in the country.
Further to this, it is expected that, following additional fieldwork in riparian areas in the north and center of the Iberian Peninsula, the species will be found in more regions.

Its affinity to acidic substrates, particularly granitic rocks, makes it much more frequently distributed in areas of the Hesperian Massif of



Fig. 2. Known Portuguese distribution of Bryum minii Podp. ex Machado-Guim. in UTM squares $(1 \mathrm{~km})$. $\odot$ - Until and including 1980; - After 1980. Mi - Minho, TM - Trásos-Montes e Alto Douro, DL - Douro Litoral, BL - Beira Litoral, BA - Beira Alta, BB - Beira Baixa, E - Estremadura, R - Ribatejo, AAI - Alto Alentejo, BAI - Baixo Alentejo, $\mathrm{Ag}$ - Algarve. 
the Iberian Peninsula and this moss has never been found in areas of limestone origin. It usually develops on acidic bedrock in temporary water courses including habitats related with Molinio-Arrhenatheretea grasslands such as Serra da Estrela (Sérgio et al. 2003). It also often colonizes rock slopes, usually in shaded alluvial forests.

SELECTION OF RECENT SPECIMENS: PORTUGAL. Minho: Ponte de Lima, Lagoas de Bertiandos e S. Pedro d'Arcos, NG3218, 2010, C. A. Garcia \& V. Novais (LISU 233456). DOURO LiTORAL: Amarante, Fridão, NF7972, 78 m, 2011, C. Garcia (LISU 239404); Celorico de Basto, Codeçoso, NF8377, 103 m, 2011, C. Garcia (LISU 239405); Valongo, NF4358, 2005, C. Vieira (CIBIO 7968, rev. C. Sérgio 2011); TRÁs-Os-MONTES E Alto Douro: Vila Nova de Foz Côa, Numão, PF4453, 2004, A. Albuquerque (LISU 207047); Mondim de Basto, Britelo, NF8583, 130 m, 2011, C. Garcia (LISU 239406); Ribeira de Pena, Cavês, NF9296, 168 m, 2011, C. Garcia \& C. Sérgio (LISU 239407); Arco de Baúlhe, Ribeira de Peio, NF8892, 139 m, 2011, C. Sérgio (LISU 239408); BEIRA ALTA: Nelas, Senhorim, PE0084, 187 m, 2011, C. Garcia \& C. Sérgio (LISU 244615); Mangualde, Cunha Baixa, PE0787, 238 m, 2011, C. Garcia \& C. Sérgio (LISU 244616); Póvoa de Cervães, PE1089, 253 m, 2011, C. Sérgio \& C. Garcia (LISU 244617); Gouveia, Cativelos, PE1089, 253 m, 2011, C. Sérgio \& C. Garcia (LISU 244618); Gouveia, Ribamondego, PE1791, 282 m, 2011, C. Sérgio \& C. Garcia (LISU 244620); Seia, Valezim, PE0968, 2005, A. Albuquerque (LISU 210186); BEIRA BAIXA: Malcata, PE6555, 2000, C. Sérgio 12747 (LISU 231319); Sabugal, Seixo do Côa, PE6781, 2004, P. Rodríguez-González (LISU 207046); Monforte da Beira, PE4600, 250 m, 2009, C. Sérgio, M. Brugués \& R. Cros (LISU 242469); Segura, Rio Erges, PE7310, 240 m, 2009, C. Sérgio, M. Brugués \& R. Cros (LISU 242470); Alto ALENTEJO: Castelo de Vide, Ribeira Maria Rasa, PD3865, 400 m, 2010, C. Sérgio 10561 (LISU 235844); BAIXO AlENTEJO: Serpa, Rio Guadiana, Pulo do Lobo, PB2085, 2000, C. Sérgio 11348 (LISU 212375); Serpa, Ribeira da Lima, PB2187, 2004, C. Sérgio, M. Brugués \& R. Cros (LISU 12374).

ACKNOWLEDGMENTS. We are grateful to the anonymous reviewers for helpful remarks on the manuscript. This research was carried out with financial support from various national projects and from studies developed for the project: Atlas and Red Data Book of Portuguese
Bryophytes (funded by the energy company EDP) which allowed revision of LISU herbarium specimens.

\section{REFERENCES}

Cezón K., Muñoz J. \& Hespanhol H. 2010. The discovery of Bryum minii Podp. ex Machado-Guim. in Spain, with new synonyms and correct authorship. Bryologist 113: 371-375.

Guerra J., Brugués M., CANo M. J. \& Cros R. M. (eds) 2010. Flora Briofítica Ibérica. Funariales, Splachnales, Schistostegales, Bryales, Timmiales. 4. Universidad de Murcia, Sociedad Española de Briología, Murcia.

Machado A. 1916. Notas de Briologia Portuguesa. Revista dos Liceus 1: 28-32.

Machado A. 1930. Sinopse das Briófitas de Portugal. Segunda parte. Musgos. Bol. Soc. Brot. 6: 180-265.

Ros R. M., Mazimpaka V., Abou-Salama U., Aleffi M., Blockeel T. L., Brugués M., Cros R. M., Dia M. G., Dirkse G. M., Draper I., El-SAadaWi W., ERdă̆ A., Ganeva A., Gabriel R., GonzÁlez-Mancebo J. M., Granger C., Herrnstadt I., Hugonnot V., Khalil K., KÜRSCHNER H., LOSADA-Lima A., Luís L., MifSUd S., Privitera M., Puglisi M., SAbOVlJević M., SÉRgio C., Shabbara H. M., Sim-Sim M., SotiauX A., TACChi R., VANDERPoORTEN A. \& Werner O. 2013. Mosses of the Mediterranean, an Annotated Checklist. Cryptog. Bryol. 34: 99-283.

SkrZyPCZAK R. 1998. Présence de Bryum minii Podp. en France. Bull. Soc. Bot. Centre-Ouest 29: 477-478.

SÉRGIO C. \& DRAPER D. 2001. Bryophyte survey as a basis for the validity of the Mediterranean isoclimatic areas in Portugal. Bocconea 13: 89-99.

SÉRGIO C. \& DRAPER D. 2002. How to evaluate species when distribution is poorly understood. The use of predictive studies for Iberian bryophytes. Portugaliae Acta Biol., Sér. $B$ 20: $37-48$.

SÉrgio C., Pierrot R. B., Cros R. M. \& Brugués M. 1999. Re-evaluation of Bryum minii Podp. (Bryaceae) and remarks about new discoveries in Portugal. J. Bryol. 21: 299-303.

SÉrgio C., Brugués M., Cros R.M., Garcia C. \& Stow S. 2011. First Bryofloristic study of the Tejo International Region (Portugal). Boletín de la Sociedad Española de Briología 37: 1-10.

SÉrgio C., Sim-Sim M., Jansen J., Garcia C. \& CARVAlho P. 2003. Bryophyte diversity and impact of land-use in seminatural grasslands in the Serra da Estrela (Portugal). Bocconea 16: 1001-1019. 